\title{
Effect of progesterone, human chorionic gonadotropin and progesterone + human chorionic gonadotropin treatment on conception rates in repeat breeder cows
}

\author{
Hasan Alkan, Huseyin Erdem \\ Selcuk University, Faculty of Veterinary Medicine, Department of Obstetrics and Gynaecology, \\ Alaeddin Keykubat Campus, Konya, Turkey \\ Received April 1, 2020 \\ Accepted December 21, 2020
}

\begin{abstract}
The aim of this study was to investigate the effects of hormonal support on the pregnancy rate in repeat breeder cows. Prostaglandin $\mathrm{F}_{2 \alpha}+$ Ovsynch oestrus synchronization protocol was applied to the cows. Following the fixed time insemination (day 0), the cows were divided into 4 groups. In Group $1(\mathrm{n}=42)$, progesterone releasing intravaginal device (PRID) was placed vaginally at $84 \mathrm{~h}$ and removed on the $9^{\text {th }}$ day after the artificial insemination. In Group $2(\mathrm{n}=40)$, the cows were administered human chorionic gonadotropin (hCG) on the $7^{\text {th }}$ day. Group 3 $(n=45)$ was applied a combination of progesterone and hCG. Group $4(n=42)$ was not given any treatment. Blood samples were collected from all cows 4 times on days 3.5, 7, 12, and 18 to evaluate progesterone concentrations. The pregnancy rates were $40.47 \%, 37.50 \%, 44.44 \%$, and $30.95 \%$ in Group $1,2,3$, and 4 , respectively $(P>0.05)$. In addition, in cows with progesterone concentrations $<2 \mathrm{ng} / \mathrm{ml}$ on day 3.5 , the pregnancy rates were found to be lower than in the cows with progesterone concentrations $>2 \mathrm{ng} / \mathrm{ml}$ in Group $4(P<0.05)$. Progesterone supplementation in cows with progesterone concentrations $<2 \mathrm{ng} / \mathrm{ml}$ appeared to increase pregnancy rates $(P<0.05)$ in Groups 1 and 3. As a result, post-insemination hormonal applications in the repeat breeder cows did not increase the pregnancy rate. However, it was concluded that determination of progesterone concentrations on day 3.5 following artificial insemination and then hormonal support in the cows with low concentrations would increased the pregnancy rate.
\end{abstract}

Pregnancy rate, $h C G$, artificial insemination, cattle

Cows that have given birth at least once, have regular sexual cycles (18-24 days), have no clinical disorders in their genital organs and/or abnormal vaginal discharge, and have not been pregnant after at least 3 artificial inseminations (AI) are called "repeat breeder cows" (Youngquist and Bierschwal 1985; Noakes et al. 2001; Ptaszynska 2009). Incidence of the repeat breeder cows varies depending on the region, environment, and management conditions of dairy farms. Earlier studies have stated that the incidence of repeat breeder cows is between 10 to 24\% (Gustafsson and Emanuelson 2002; Salasel et al. 2010; Yusuf et al. 2012).

It is well-known that repeat breeder cow problem is not due to a single cause, but it is a multifactorial challenge (Yusuf et al. 2010; Perez-Marin et al. 2012). Although many factors are effective in the repeat breeder problem, two of the most important reasons are suggested to be fertilization failures and early embryonic deaths (Bilby 2008; Amiridis et al. 2009). The incidence of pregnancy loss due to fertilization failures and embryonic death at the early stages in the repeat cows was reported to be around $29-40 \%$ and $29-47 \%$, respectively (Ayalon 1978; Diskin et al. 2012).

Embryos are more susceptible to mortality especially during the transition from the morula stage to the blastocyst (days 5-8) (Inskeep and Dailey 2005). Repeat breeder cows also have a large proportion of embryonic losses around days 5-7 after insemination when the embryo enters the uterus and begins to synthesize its own proteins (Barrett et al. 2004; Diskin and Morris 2008). The maternal progesterone concentration is

Address for correspondence:

Hasan Alkan

Selcuk University Faculty of Veterinary Medicine

Department of Obstetrics and Gynaecology

Phone: +90332 2232671

Alaeddin Keykubat Campus, Konya, Turkey 
also critical during early embryonal development since it orchestrates many molecular, biochemical, and physiological interactions that affect the growth, development and viability of the embryo in the uterus. In addition, progesterone regulates the degree of uterine secretions, development of the conceptus, production of interferon tau (IFN-t) by the conceptus that suppresses the luteolysis, and prostaglandin $\mathrm{F}_{2 \alpha}\left(\mathrm{PGF}_{2 \alpha}\right)$ release (Morris and Diskin 2008). Therefore, the insufficient release of progesterone leads to poor development of the embryo and ultimately to early embryonic loss (Mann and Lamming 1999).

Hormones such as progesterone, gonadotropin-releasing hormone $(\mathrm{GnRH})$ and human chorionic gonadotropin (hCG) are widely used to increase the conception rate in cows by increasing the concentration of progesterone (BonDurant et al. 1991; Khoramian et al. 2011; Ergene 2012; Pandey et al. 2016). Progesterone supplementation; alone or in combination with other hormones, can be used at different stages of the oestrous cycle to maintain pregnancy and increase maternal recognition of pregnancy. In these hormonal applications following AI, there may be differences between the rates of conception (Yan et al. 2016). Some studies have reported that progesterone supplementation (Ghasemzadeh-Nava et al. 2007; Jeong et al. 2016; Parr et al. 2017) and hCG administration (Kendall et al. 2009; Khoramian et al. 2011; Sánchez et al. 2018) increase the pregnancy rate, while some studies (Shams-Esfandabadi and Shirazi 2007; Ergene 2012) have reported no effect. Yan et al. (2016) reported that the benefit of progesterone supplementation on fertility of cows required exogenous progesterone supplementation to start between Day 3 to 7 . Besbaci et al. (2019) reported that the use of hCG after AI should be focused on cows expected to have low or moderate fertility. However, in these studies, differences in the evaluation of the efficacy of hormonal applications may be in question since the evaluations made according to the progesterone concentration during the applications are very few in repeat breeder cows. Therefore, the aim of this study was to investigate the effects of progesterone concentration and hormonal supplementation after AI on the pregnancy rates in the repeat breeder cows.

\section{Materials and Methods}

Ethical approval (2016/49) for this study was obtained from the Ethics Committee of Experimental Animals Production and Research Center of Selcuk University Veterinary Faculty.

\section{Location}

The study was conducted at the Kocas Agricultural Farm ( $\left.38^{\circ} 27^{\prime} 27.8^{\prime \prime N}, 33^{\circ} 50^{\prime} 20.3^{\prime \prime} \mathrm{E}\right)$. There were a total of 4,000 Holstein cattle with 1,700 in lactation. The 305-day lactation milk yield on the farm ranged between $6,750-11,125 \mathrm{~kg}$ and the average milk yield was $26.3 \mathrm{~kg}$. The cows were housed in groups of 150 in paddocks. The cows at the farm were regularly administered vaccines for brucella, infectious bovine rhinotracheitis, bovine viral diarrhoea, enterotoxaemia, foot and mouth disease, smallpox and fungus. The rations of the animals were prepared as a total mix ration (TMR) and feeding was done twice daily. In the diet, corn silage, alfalfa silage, dry alfalfa, vetch, triticale, straw, concentrated feed, vitamin and mineral supplement were provided.

\section{Animals}

In this study, 169 healthy Holstein cows (aged 2.5-7 years, $<250$ days in milk, DIM) were included in this study based on the following criteria: 1) they had given birth at least once, 2) they had regular oestrous cycles, 3) no problems were found in their genital system during the rectal palpation/ultrasonographic examination, 4) they had been inseminated at least $3 \times$ without becoming pregnant. Cows that experienced problems during or after labour such as difficult labour, retentio secundinarum, metritis, etc., were not included in the study.

The animals were first selected through the Dairy Plan (GEA Farm Technologies, USA) that was already being used by the farm management. Rectal examination and ultrasonographic examination $(6.0 \mathrm{MHz}$ linear probe, Falcovet, Pie Medical, Netherlands) were then performed. During these examinations, ovaries, oviducts, uterus and cervix were evaluated (Mortimer et al. 1997). Animals that had problems such as adhesions, cysts and metritis in genital organs during the examinations were not included in the study. Moreover, cows with a corpus luteum ( $>1.5 \mathrm{~cm}$ diameter) on ovaries were included in the study. 


\section{Synchronization}

The cows were first pre-synchronized with $\mathrm{PGF}_{2 \alpha}$ and then Ovsynch protocol was applied. For this purpose, an intramuscular injection of $\mathrm{PGF}_{2 \alpha}\left(25 \mathrm{mg}\right.$, Dinoprost, Dinolytic ${ }^{\circledR}$, Zoetis, Istanbul, Turkey) was performed. Twelve days later, $10 \mathrm{mg}$ of $\mathrm{GnRH}$ (Buserelin, Receptal ${ }^{\circledR}$, Intervet, Istanbul, Turkey) was administered intramuscularly, and the injection of $\mathrm{PGF}_{2 \alpha}$ was given intramuscularly after 7 days, which was followed by second injection of $\mathrm{GnRH} 48 \mathrm{~h}$ later. Fixed time AI was performed $12-16 \mathrm{~h}$ after the last injection.

\section{Experimental groups}

Following the fixed time of AI (day 0) the cows were randomly divided into 4 groups. The cows in Group 1 (progesterone group, $\mathrm{n}=42$ ) were inserted a progesterone releasing intravaginal device (PRID) intravaginally (1.55 g, PRID Delta ${ }^{\circledR}$, Ceva, Istanbul, Turkey) at $84 \mathrm{~h}$ (day 3.5). The device was removed on day 9. Group 2 of cows (hCG group, $\mathrm{n}=40$ ) was administered $1500 \mathrm{IU}$ hCG (Chorulon, Intervet, Istanbul, Turkey) intramuscularly on day 7. In Group 3 (progesterone + hCG group, $n=45$ ), the cows received a PRID and hCG combination as applied in Groups 1 and 2. Group 4 of cows (Control group, $n=42$ ) did not receive any treatment and was evaluated as control.

\section{Blood sample collection}

To determine progesterone concentrations, blood samples were taken on days $3.5\left(84^{\text {th }} \mathrm{h}\right), 7,12$, and 18 days after AI (Carter et al. 2008; Batista et al. 2019). Blood samples from vena coccygea were collected into $10 \mathrm{ml}$ vacuum ethylenediaminetetraacetic acid tubes. Plasma was separated by centrifugation at $3,000 \times g$ for $15 \mathrm{~min}$. Separated plasma was stored at $-20{ }^{\circ} \mathrm{C}$ until analysis. Progesterone analysis (Roche Progesterone kit, Roche Diagnostics, Indianapolis, USA) was performed by electronchemulisence immunoassay (Cobas e601, Roche, Germany).

\section{Pregnancy diagnosis}

Pregnancy diagnosis was performed on day 30 with real-time ultrasonography $(6.0 \mathrm{MHz}$ linear probe, Falcovet, Pie Medical, Netherlands) based on the presence of a hypoechogenic embryo in a non-echogenic region of the uterus. Pregnant cows were examined by ultrasonography for the second time on day 45 to determine late embryonic deaths that occurred between 30-45 days. Embryonic death was considered when the embryo could not be found, the heart rate of the embryo could not be detected or the embryonal fluids were resorbed.

\section{Statistical analyses}

For the analysis of the data, SPSS 25 (IBM SPSS Statistics for Windows, Version 25.0, released 2017, IBM Corp., Armonk, NY, USA) statistical package program was used. Data (age, lactation number, milk yield, days in milk, number of artificial inseminations, body condition score at the beginning of the experiment) were presented as mean \pm standard deviation, median (maximum-minimum) percentage, and frequency values. The suitability of the data for repeated measures analysis of variance (progesterone concentration on days 3.5, 7, 12, and 18) was evaluated by Mauchy's Sphericity Test and Box-M Variance Homogeneity Test. For the comparison of means, repeated measures variance analysis was used. If the parametric tests (repeated measurements in factorial order) did not meet the prerequisites of variance analysis, Greenhouse and Geisser (1959) or Huynh and Feldt (1976) tests with degree of freedom correction were used. Multiple comparisons among groups were performed using adjusted Bonferroni test. Variables were evaluated after checking the normality and homogeneity of variance prerequisites (Shapiro Wilk and Levene test). When performing data analysis, independent 2 groups $t$-test (Student's $t$-test) was used for comparison of two groups and when it did not provide the prerequisites, Mann-Whitney $U$ test was used. For three and more group comparisons (comparison of pregnancy rates between groups on day 30), One Way Analysis of Variance, Tukey HSD test, Kruskal Wallis or Bonferroni-Dunn tests were used. Categorical data (on days 3.5 progesterone concentrations; $<1,1-2$, and $>2 \mathrm{ng} / \mathrm{ml}$ ) were analysed by Fisher's exact test and chi squared test. In cases where the expected frequencies were less than $20 \%$, Monte Carlo simulation method was used to include these frequencies in the analysis. For the significance level of the tests, $P<0.05$ and $P<0.01$ were accepted.

\section{Results}

In this study, a total of 169 Holstein cows identified as repeat breeder cows were used. Mean age (months), lactation number, milk yield ( $\mathrm{kg}$ ), days in milk, number of insemination and body condition scores (BCS) are presented in Table 1.

The pregnancy rates on day 30 were $40.47 \%$ in Group $1,37.50 \%$ in Group 2, $44.44 \%$ in Group 3 and $30.95 \%$ in Group $4(P>0.05)$. The pregnancy rates on day 45 among the cows that were determined to be pregnant on day 30 were $38.09 \%$ in Group 1, 37.50\% in Group 2, $42.22 \%$ in Group 3, and $28.57 \%$ in Group $4(P>0.05)$. The rate of late pregnancy loss on day 30 and 45 following AI is given Table 2 . 
Mean plasma progesterone concentrations on days 3.5, 7, 12, and 18 are presented in Table 3 . There were no significant differences in plasma progesterone concentrations on day 3.5 between the groups. Plasma progesterone concentrations on day 7 were higher in the groups treated with PRID (Groups 1 and 3) compared to hCG (Group 2) and control (Group 4) $(P<0.05)$. Plasma progesterone concentrations on days 12 and 18 were higher in the hCG treated groups (Groups 2 and 3) compared to the control and PRID groups $(P<0.05)$.

The cows were sub-grouped within a group based on the concentration on day 3.5 after insemination as $<1,1-2,>2 \mathrm{ng} / \mathrm{ml}$ and the pregnancy rates on day 30 were compared (Table 4$)$. On day 3.5 , ratio of cows with progesterone concentration $<2 \mathrm{ng} / \mathrm{ml}$ was found to be $69.05 \%$ in Group 1, 75.0\% in Group 2, 68.88\% in Group 3 , and $73.80 \%$ in Group 4. This result indicates that progesterone concentrations were low in repeat breeder cows earlier in the cycle. The pregnancy rate was increased in Group 1 when PRID was applied on day 3.5 in cows with progesterone concentrations $<1$ and $1-2 \mathrm{ng} / \mathrm{ml}(P<0.05)$. It was determined that progesterone supplementation to cows with progesterone concentration $<2 \mathrm{ng} / \mathrm{ml}$ on day 3.5 after insemination had a positive effect. The pregnancy rate in cows in the control group with low progesterone concentrations was found to be low $(P<0.05)$.

\section{Discussion}

The most important problems of the modern dairy cattle industry are the longer calving to pregnancy interval, the increase in the number of AI per pregnancy, and the decrease in the breeding value of the cow due to the failure in getting pregnant. In addition, economic loss due to low number of calves, additional drug costs, and an increased number of reformed animals are some of the immediate consequences of these problems (Bartlett et al. 1985; Mcsweeney 2004; Dochi et al. 2008; Perez-Marin et al. 2012). Repeat breeder syndrome is an important factor in the emergence of these problems.

In repeat breeder cows, progesterone concentrations in the early luteal period after AI are very important for a successful pregnancy (Perez-Marin et al. 2012). Studies have shown that low concentrations of progesterone in cows cause even higher rate of early embryonic deaths (Thatcher et al. 2001; McNeill et al. 2006). Progesterone is a requirement for early histotrophic nutrition of the conceptus (Santos et al. 2004) and is involved in the prevention of luteolysis and stimulation of interferon tau release during the maternal recognition of pregnancy (Mann and Lamming 1999). Stronge et al. (2005) reported that the embryo developed better and the embryonic mortality rate was lower in cows with milk progesterone concentrations of $7.4 \mathrm{ng} / \mathrm{ml}$ on day 5 of the cycle. Therefore, a delay in the increase of progesterone concentration in the early luteal period (days 4-7) after AI adversely affects embryonic development. Furthermore, Mann 
Table 2. Pregnancy rates and the rate of late pregnancy loss on days 30 and 45 following artificial insemination.

\begin{tabular}{lccc}
\hline Group & Day 30 (\%) & Day 45 (\%) & Late pregnancy loss (\%) \\
\hline Group 1 (PRID) & $17 / 42(40.47)^{\mathrm{a}}$ & $16 / 42(38.09)^{\mathrm{a}}$ & $1 / 17(5.88)^{\mathrm{a}}$ \\
Group 2 (hCG) & $15 / 40(37.50)^{\mathrm{a}}$ & $15 / 40(37.50)^{\mathrm{a}}$ & - \\
Group 3 (PRID + hCG) & $20 / 45(44.44)^{\mathrm{a}}$ & $19 / 45(42.22)^{\mathrm{a}}$ & $1 / 20(5.00)^{\mathrm{a}}$ \\
Group 4 (Control) & $13 / 42(30.95)^{\mathrm{a}}$ & $12 / 42(28.57)^{\mathrm{a}}$ & $1 / 13(7.69)^{\mathrm{a}}$ \\
\hline
\end{tabular}

a - differences within the columns $(P>0.05)$; PRID - progesterone releasing intravaginal device; hCG - human chorionic gonadotropin)

Table 3. Plasma progesterone values on days 3.5, 7, 12, and 18 after artificial insemination.

\begin{tabular}{lcccc}
\hline Group & Day 3.5 $(\mathrm{ng} / \mathrm{ml})$ & Day $7(\mathrm{ng} / \mathrm{ml})$ & Day 12 $(\mathrm{ng} / \mathrm{ml})$ & Day $18(\mathrm{ng} / \mathrm{ml})$ \\
\hline Group 1 (PRID) & $1.86 \pm 1.19^{\mathrm{aA}}$ & $5.15 \pm 1.52^{\mathrm{bdA}}$ & $6.43 \pm 2.36^{\mathrm{cA}}$ & $4.54 \pm 4.19^{\mathrm{dA}}$ \\
Group 2 (hCG) & $1.83 \pm 1.21^{\mathrm{aA}}$ & $4.54 \pm 1.26^{\mathrm{bdB}}$ & $8.90 \pm 3.25^{\mathrm{cB}}$ & $7.74 \pm 3.85^{\mathrm{dB}}$ \\
Group 3 (PRID + hCG) & $1.81 \pm 1.46^{\mathrm{aA}}$ & $5.45 \pm 1.50^{\mathrm{bdA}}$ & $9.88 \pm 3.57^{\mathrm{cB}}$ & $9.45 \pm 5.4^{\mathrm{dB}}$ \\
Group 4 (Control) & $1.84 \pm 1.03^{\mathrm{aA}}$ & $4.07 \pm 1.29^{\mathrm{bcB}}$ & $6.37 \pm 2.27^{\mathrm{cA}}$ & $5.49 \pm 4.17^{\mathrm{cA}}$ \\
\hline
\end{tabular}

a-d - differences within the rows, A-D - differences within the columns $(P<0.05)$; PRID - progesterone releasing intravaginal device; hCG - human chorionic gonadotropin

Table 4. Pregnancy rates (PR) on day 30 in reference to the progesterone concentrations on day 3.5 following artificial insemination.

\begin{tabular}{lcccccccc}
\hline \multirow{2}{*}{ Day 3.5 P4 (ng/ml) } & \multicolumn{2}{c}{ Group 1 (PRID) } & & Group 2 (hCG) & & Group 3 (PRID + hCG) & \multicolumn{2}{c}{ Group 4 (Control) } \\
\cline { 2 - 9 } & $\mathrm{n}$ & PR (\%) & $\mathrm{n}$ & PR $(\%)$ & \multicolumn{1}{c}{$\mathrm{n}$} & PR $(\%)$ & $\mathrm{n}$ & PR $(\%)$ \\
\hline$<1$ & 7 & $4 / 7(57.14)^{\mathrm{aA}}$ & 9 & $3 / 9(33.33)^{\mathrm{abA}}$ & 3 & $2 / 3(66.66)^{\mathrm{aA}}$ & 12 & $1 / 12(8.33)^{\mathrm{bA}}$ \\
$1-2$ & 22 & $11 / 22(50.0)^{\mathrm{aA}}$ & 21 & $8 / 21(38.09)^{\mathrm{aA}}$ & 28 & $14 / 28(50.0)^{\mathrm{aA}}$ & 19 & $6 / 19(31.57)^{\mathrm{aAB}}$ \\
$>2$ & 13 & $2 / 13(15.38)^{\mathrm{aB}}$ & 10 & $4 / 10(40.0)^{\mathrm{abA}}$ & 14 & $4 / 14(28.57)^{\mathrm{abB}}$ & 11 & $6 / 11(54.54)^{\mathrm{bB}}$ \\
\hline
\end{tabular}

a-b - differences within the rows, ${ }^{\mathrm{A}-\mathrm{B}}$ - differences within the columns $(P<0.05)$; PRID - progesterone releasing intravaginal device; hCG - human chorionic gonadotropin

and Lamming (1999) found that cows with milk progesterone concentrations $>3 \mathrm{ng} / \mathrm{ml}$ on day 4 after AI had a higher pregnancy rate. In the present study, we showed that the pregnancy rate was low when the progesterone concentration was $<2 \mathrm{ng} / \mathrm{ml}$, and increased in the progesterone-supplemented cows. Therefore, it is considered that progesterone supplementation to repeat breeder cows with low progesterone concentrations (i.e., plasma progesterone concentrations $<2 \mathrm{ng} / \mathrm{ml}$ ) in the early luteal period could be beneficial in increasing the pregnancy rate. Based on the results of previously published studies, it is known that progesterone supplementation accelerates the embryo development and stimulates a sufficient release of IFN-t during the maternal recognition of pregnancy (Starbuck et al. 2001; Ghanem and Nishibori 2015; Yan et al. 2016). However, it was determined that progesterone supplementation in cows with a progesterone level of $>2 \mathrm{ng} / \mathrm{ml}$ at 3.5 days following AI, may have a negative effect on the pregnancy rate. Starbuck et al. (2001) also reported that progesterone supplementation had no effect on the pregnancy rate in cows with a progesterone level of $2-3 \mathrm{ng} / \mathrm{ml}$ on the $5^{\text {th }}$ day following insemination. This situation is thought to be caused by the increase of progesterone before the required level and time following insemination. Stronge et al (2005) reported a negative relationship between progesterone concentrations and pregnancy rates on the $4^{\text {th }}$ day following insemination. In other words, it is thought that exogenous progesterone administration to cows with normal progesterone concentrations following insemination may have negative/ 
neutral effects. For this reason, it is thought that it would be more beneficial to apply progesterone support to cows with low progesterone by determining its concentration in the early period after insemination in repeat breeder cows.

Roelofs etal.(2004) showed that progesterone concentration began to increase $63.7 \pm 1.7 \mathrm{~h}$ following the onset of oestrus and $33.8 \pm 1.1 \mathrm{~h}$ after the ovulation. The progesterone concentration was found to be around $2 \mathrm{ng} / \mathrm{ml} 80 \mathrm{~h}$ after the ovulation. Earlier studies reported that blood progesterone concentrations were lower than $2 \mathrm{ng} / \mathrm{ml}$ in the early luteal period in approximately 34-75\% of repeat breeder cows (Kimura et al. 1987; Bå ge et al. 2002; Kendall et al. 2009). In the present study, the ratio of cows with blood progesterone concentrations $<2 \mathrm{ng} / \mathrm{ml}$ in the early luteal period (day $3.5=84 \mathrm{~h}$ after insemination) was about $72 \%$. Our results and earlier studies (Starbuck et al. 2001; Ghanem and Nishibori 2015) clearly suggest that one of the most important reasons for low pregnancy rates in repeat breeder cows might be low progesterone concentrations in the early luteal period. Moreover, in the control group, the pregnancy rates in the cows with plasma progesterone concentrations of $<1 \mathrm{ng} / \mathrm{ml}, 1-2 \mathrm{ng} / \mathrm{ml}$ and $<2 \mathrm{ng} / \mathrm{ml}$ on day 3.5 were $8.33 \%, 31.57 \%$, and $54.54 \%$, respectively $(P<0.05)$. However, when progesterone supplementation was applied to cows with low progesterone concentrations in Group 1, the pregnancy rates were found to be increased.

The main aim of the studies focused on improving fertility in repeat breeder cows is to increase the pregnancy rates by elevating the progesterone concentrations with different hormonal applications (BonDurant et al. 1991; Khoramian et al. 2011; Ergene 2012; Pandey et al. 2016). In this study, the effect of administration of PRID and hCG either alone or combined during the early phase of the oestrous cycle on pregnancy rates was investigated. Although there was no significant difference in the pregnancy rates overall among the groups of the study, numerical increases were observed due to hormonal supplementations in the treated groups. Especially, PRID administration was found to increase the rate of pregnancy in repeat breeder cows with progesterone concentrations $<2 \mathrm{ng} / \mathrm{ml}$ on day $3.5(P<0.05)$. Cows with low progesterone concentrations $(<2 \mathrm{ng} / \mathrm{ml})$ on day 3.5 after AI in the control group were found to have a very low conception rate $(P<0.05)$. It is thought that the development of the embryo may be accelerated by increasing the progesterone concentration in the early luteal period with the application of exogenous progesterone, thus contributing to the release of sufficient IFN-t during the maternal recognition of pregnancy (Mann et al. 2006; Carter et al. 2008). In a study by Khoramian et al. (2011), hCG and controlled internal drug release (CIDR) applications after AI in repeat breeder cows led to higher conception rates. Application of CIDR following AI between days 5-12 (Hokmabad et al. 2012), days 5-9 (GhasemzadehNava et al. 2007) and days 3.5-18 (Jeong et al. 2016) was reported to be successful in increasing the conception rate. Garcia-Ispierto and López-Gatius (2017) reported that progesterone supplementation either early (3-5 days) or late (15-17 days) in the cycle increased the conception rate.

The timing and duration of hormonal supplementation after AI in the repeat breeder cows may have positive and/or negative effects on the development of the corpus luteum and embryo (Parr et al. 2017). Short-term progesterone supplementation is thought to be more beneficial in the early luteal period (Yan et al. 2016). Parr et al. (2017) reported that while progesterone supplementation on day 4 following AI provided better embryo development, long-term administration adversely affected the corpus luteum development. Thuemmel et al. (1992) stated that exogenous progesterone applications do not affect the amount of progesterone to be produced from the corpus luteum. Exogenous progesterone increases the amount of progesterone in vena jugularis, resulting in less progesterone transfer from the ovary to the peripheral circulation. Thus, the amount of circulating progesterone can be increased to reduce the embryonic mortality rate. Exogenous (through PRID) and 
indirect endogenous progesterone (through secondary corpus luteum formation by hCG) supplementation in this study numerically increased the pregnancy rate. Since progesterone supplementation increases the secretion of endometrial protein and growth factors, early embryonic development accelerates which enables the embryo to reach a sufficient size at the time of maternal recognition. Therefore, the embryo secretes a copious amount of IFN-t and incidence of embryonic deaths attenuates (Carter et al. 2008). If delayed or low progesterone concentrations occur, elongation of the conceptus and endometrial transcription are negatively affected, leading to lower pregnancy rates (Garrett et al. 1988; Forde et al. 2011).

One way of increasing progesterone concentrations in the early luteal period in repeat breeder cows is the use of hormones such as hCG and GnRH (Pandey et al. 2016). These hormones can also be used in combination with CIDR or PRID (Kendall et al. 2009). It has been reported that hCG treatment on days 4,5 or 6 in the cycle increased the blood progesterone concentrations and pregnancy rates (Kendall et al. 2009; Alnimer and Shamoun 2015; Pandey et al. 2016). In the present study, pregnancy rates numerically increased as a result of hCG alone or combined PRID. The hCG treatment causes a growth in the primary corpus luteum size, increases luteal cell number, induces formation of accessory corpus luteum by ovulating/luteinizing the dominant follicle, and thereby contributes to increasing the pregnancy rate (Fricke et al. 1993; Santos et al. 2001).

There have been many studies that indicate beneficial or no effects of the postinsemination hormone applications on the pregnancy rates. Ergene and Alaçam (2011) reported that the application of PRID to repeat breeder cows on different days (4-11 days, 11-18 days) after AI did not increase the conception rate, however, it was effective in increasing the progesterone concentration. Other studies also determined that progesterone supplementation between days 5-19 did not change the rate of conception (ShamsEsfandabadi and Shirazi 2007). Arndt et al. (2009) reported that long-term exogenous progesterone administration following AI is not effective in reducing pregnancy losses.

In conclusion, although PRID, hCG, and PRID + hCG applications in the early luteal period did not significantly increase the pregnancy rate in the repeat breeder cows in the present study, the number of pregnancies was higher in hormonally treated groups compared to the control group. In addition, progesterone concentrations in the early luteal period (day 3.5) were found to be low in repeat breeder cows, but progesterone concentration $<2 \mathrm{ng} / \mathrm{ml}$ on day 3.5 was associated with lower pregnancy rates. It was concluded that progesterone supplementation to repeat breeder cows with low progesterone concentrations after AI could be beneficial in improving the pregnancy rates.

\section{Conflict of interest}

The authors declare that there is no conflict of interest.

\section{Acknowledgments}

This study was financially supported by the Selcuk University Scientific Research Projects Coordinator (Project no. 16102021).

\section{References}

Alnimer MA, Shamoun AI 2015: Treatment with hCG 4 or 6 days after TAI to improve pregnancy outcomes in repeat-breeding dairy cows. Anim Reprod Sci 157: 63-70

Amiridis GS, Tsiligianni T, Dovolou E, Rekkas C, Vouzaras D, Menegatos I 2009: Combined administration of gonadotropin-releasing hormone, progesterone, and meloxicam is an effective treatment for the repeat-breeder cow. Theriogenology 72: 542-548

Arndt WJ, Holle AJ, Bauer ML, Kirsch JD, Schimek DE, Odde KG, Vonnahme KA 2009: Effect of postinsemination progesterone supplementation on pregnancy rate in dairy cows. Can J Vet Res 73: 271-274

Ayalon N 1978: A review of embryonic mortality in cattle. Reprod Fertil Dev 54: 483-493 
Båge R, Gustafsson H, Larsson B, Forsberg M, Rodríguez-Martínez H 2002: Repeat breeding in dairy heifers: Follicular dynamics and estrous cycle characteristics in relation to sexual hormone patterns. Theriogenology 57: 2257-2269

Barrett HB, Boyd H, Mihm M 2004: Failure to conceive and embryonic loss. In: Andrews AH, Blowey RW, Boyd H, Eddy RG (Eds): Bovine Medicine: Disease and Husbandry of Cattle. Blackwell Science, Oxford, pp. $552-576$

Bartlett PC, Kirk JH, Mather EC 1985: Repeated insemination in Michigan Holstein-Friesian cattle: incidence, descriptive epidemiology and estimated economic impact. Theriogenelogy 26: 309-322

Batista EOS, Cardoso BO, Oliveira ML, Cuadros FDC, Mello BP, Sponchiado M, Monteiro BM, Pugliesi G, Binelli M 2019: Supplemental progesterone induces temporal changes in luteal development and endometrial transcription in beef cattle. Domest Anim Endocrinol 68: 126-134

Besbaci M, Abdelli A, Minviel J, Belabdi I, Kaidi R, Raboisson D 2019: Association of pregnancy per artificial insemination with gonadotropin-releasing hormone and human chorionic gonadotropin administered during the luteal phase after artificial insemination in dairy cows: A meta-analysis. J Dairy Sci 103: 2006-2018

Bilby BTR 2008: Getting those repeat breeders bred. Western Dairy News 8: 145-146

BonDurant RH, Revah I, Franti C, Harman RJ, Hird D, Klingborg D, McCloskey M, Weaver, L, Wilgenberg B 1991: Effect of gonadotropin-releasing hormone on fertility in repeat-breeder California dairy cows. Theriogenelogy 35: 365-374

Carter F, Forde N, Duffy P, Wade M, Fair T, Crowe MA, Evans ACO, Kenny DA, Roche JF, Lonergan P 2008 : Effect of increasing progesterone concentration from Day 3 of pregnancy on subsequent embryo survival and development in beef heifers. Reprod Fert Develop 20: 368-375

Diskin MG, Morris DG 2008: Embryonic and early foetal losses in cattle and other ruminants. Reprod Domest Anim 43: 260-267

Diskin MG, Parr MH, Morris DG 2012: Embryo death in cattle: An update. Reprod Fert Develop 24: $244-251$

Dochi O, Takahashi K, Hirai T, Hayakawa H, Tanisawa M, Yamamoto Y, Koyama H 2008: The use of embryo transfer to produce pregnancies in repeat-breeding dairy cattle. Theriogenology 69: 124-128

Ergene O 2012: Progesterone concentrations and pregnancy rates of repeat breeder cows following postinsemination PRID and GnRH treatments. Turk J Vet Anim Sci 36: 283-288

Ergene O, Alaçam E 2011: Progesterone concentrations and pregnancy rates of repeat breeder cows following postinsemination PRID and GnRH treatments. Lucr Ştiinţifice 55: 315-318

Forde N, Beltman ME, Duffy GB, Duffy P, Mehta JP, O’Gaora P, Roche JF, Lonergan P, Crowe MA 2011: Changes in the endometrial transcriptome during the bovine estrous cycle: effect of low circulating progesterone and consequences for conceptus elongation. Biol Reprod 84: 266-278

Fricke PM, Reynolds LP, Redmer DA 1993: Effect of human chorionic gonadotropin administered early in the estrous cycle on ovulation and subsequent luteal function in cows. J Anim Sci 71: 1242-1246

Garcia-Ispierto I, López-Gatius F 2017: Progesterone supplementation in the early luteal phase after artificial insemination improves conception rates in high-producing dairy cows. Theriogenology 90: 20-24

Garrett JE, Geisert RD, Zavy MT, Morgan GL 1988: Evidence for maternal regulation of early conceptus growth and development in beef cattle. J Reprod Fertil 84: 437-446

Ghanem ME, Nishibori M 2015: Effects of season on plasma progesterone profiles in repeat breeding cows. Vet Med-Czech 60: 227-234

Ghasemzadeh-Nava H, Kohsari H, Tajik P 2007: Maintance of pregnancy in repeat breeder dairy cows by CIDR administration after breeding. Pak J Biol Sci 10: 2402-2406

Greenhouse SW, Geisser S 1959: On methods in the analysis of profile data. Psychometrika 24: $95-112$

Gustafsson H, Emanuelson U 2002: Characterisation of the repeat breeding syndrome in swedish dairy cattle. Acta Vet Scand 43: 115-125

Hokmabad RV, Sarabi AH, Mosaferi S 2012: Comparative study of after insemination use of CIDR and GnRH in fertility rate improvement in repeat breeder cows. Int Res J Biol Sci 7: 204-205

Huynh H, Feldt LS 1976: Estimation of the box correction for degrees of freedom from sample data in randomized block and split-plot designs. J Educ Behav Stat 1: 69-82

Inskeep EK, Dailey RA 2005: Embryonic death in cattle. Vet Clin N Am-Food A 21: 437-461

Jeong JK, Choi IS, Kang HG, Hur TY, Kim IH 2016: Effects of gonadotropin-releasing hormone administration or a controlled internal drug-releasing insert after timed artificial insemination on pregnancy rates of dairy cows. J Vet Sci 17: 577-582

Kendall NR, Flint APF, Mann GE 2009: Incidence and treatment of inadequate postovulatory progesterone concentrations in repeat breeder cows. Vet J 181: 158-162

Khoramian B, Farzaneh N, Talebkhan Garoussi M, Mohri M 2011: Comparison of the effects of gonadotropinreleasing hormone, human chorionic gonadotropin or progesterone on pregnancy per artificial insemination in repeat-breeder dairy cows. Res Vet Sci 90: 312-315

Kimura M, Nakao T, Moriyoshi M, Kawata K 1987: Luteal phase deficiency as a possible cause of repeat breeding in dairy cows. Br Vet J 143: 560-566

Mann GE, Lamming GE 1999: The influence of progesterone during early pregnancy in cattle. Reprod Domest Anim 34: 269-274 
Mann GE, Fray MD, Lamming GE 2006: Effects of time of progesterone supplementation on embryo development and interferon- $\tau$ production in the cow. Vet J 171: 500-503

McNeill RE, Diskin MG, Sreenan JM, Morris DG 2006: Associations between milk progesterone concentration on different days and with embryo survival during the early luteal phase in dairy cows. Theriogenology $\mathbf{6 5}$ : $1435-1441$

McSweeney K 2004: Embryonic loss : What causes it, what amount is normal, and how do I manage it? Available at: https://www.cvmbs.colostate.edu/ilm/proinfo/cdn/2004/Jan04EmbryonicLoss.pdf. Accessed August 18, 2018

Morris D, Diskin M 2008: Effect of progesterone on embryo survival. Animal 2: 1112-1119

Mortimer RG, Farin PW, Stevens RD 1997: Reproductive examination of the non- pregnant cow. In: Youngquist RS (Ed.): Current Therapy in Large Animal Theriogenology. Saunders Co., Philadelphia, pp. 268-275

Noakes DE, Parkinson TJ, England W 2001: Arthur's Veterinary Reproduction and Obstetrics. W.B. Saunders, London, pp. 381-472

Pandey NKJ, Gupta HP, Prasad S, Sheetal SK 2016: Plasma progesterone profile and conception rate following exogenous supplementation of gonadotropin-releasing hormone, human chorionic gonadotropin, and progesterone releasing intra-vaginal device in repeat-breeder crossbred cows. Vet World 9: 559-562

Parr MH, Scully S, Lonergan P, Evans ACO, Crowe MA, Diskin MG 2017: Establishment of critical timing of progesterone supplementation on corpus luteum and embryo development in beef heifers. Anim Reprod Sci 180: $1-9$

Perez-Marin CC, Moreno LM, Calero GV 2012: Clinical approach to the repeat breeder cow syndrome. In: PerezMarin CC (Ed.): A Bird's-eye View of Veterinary Medicine. InTech, Rijeka, pp. 337-362

Ptaszynska M 2009: Compendium of Animal Reproduction. Intervet Schering-Plough Animal Health

Roelofs JB, Bouwman EG, Dieleman SJ, Van Eerdenburg FJCM, Kaal-Lansbergen LMTE, Soede NM, Kemp B 2004: Influence of repeated rectal ultrasound examinations on hormone profiles and behaviour around oestrus and ovulation in dairy cattle. Theriogenology 62: 1337-1352

Salasel B, Mokhtari A, Taktaz T 2010: Prevalence, risk factors for and impact of subclinical endometritis in repeat breeder dairy cows. Theriogenology 74: 1271-1278

Sánchez JM, Randi F, Passaro C, Mathew DJ, Butler ST, Lonergan P 2018: Effect of human chorionic gonadotrophin administration 2 days after insemination on progesterone concentration and pregnancy per artificial insemination in lactating dairy cows. J Dairy Sci 101: 6556-6567

Santos JEP, Thatcher WW, Chebel RC, Cerri RLA, Galvão KN 2004: The effect of embryonic death rates in cattle on the efficacy of estrus synchronization programs. Anim Reprod Sci 82-83: 513-535

Santos JEP, Thatcher WW, Pool L, Overton MW 2001: Effect of human chorionic gonadotropin on luteal function and reproductive performance of high-producing lactating Holstein dairy cows. J Anim Sci 79: 2881-2894

Shams-Esfandabadi N, Shirazi A 2007: Evaluation of the effect of muscular injection of progesterone on days 2-5 following insemination on pregnancy rate in dairy cows. Pak J Biol Sci 10: 152-155

Starbuck GR, Darwash AO, Mann GE, Lamming GE 2001: The detection and treatment of post insemination progesterone insufficiency in dairy cows. BSAP Occas Publ 26: 447-450

Stronge AJH, Sreenan JM, Diskin MG, Mee JF, Kenny DA, Morris DG 2005: Post-insemination milk progesterone concentration and embryo survival in dairy cows. Theriogenology 64: 1212-1224

Thatcher WW, Moreira F, Santos JEP, Mattos RC, Lopes FL, Pancarci SM, Risco CA 2001: Effects of hormonal treatments on reproductive performance and embryo production. Theriogenology 55: 75-89

Thuemmel AE, Gwazdauskas FC, Whittier WD, McGilliard ML 1992: Effect of progesterone supplementation in repeat-breeder cattle on conception and plasma progesterone. J Endocrinol Invest 15: 393-396

Yan L, Robinson R, Shi Z, Mann G 2016: Efficacy of progesterone supplementation during early pregnancy in cows: A meta-analysis. Theriogenology 85: 1390-1398.e1

Youngquist RS, Bierschwal CJ 1985: Clinical management of reproductive problems in dairy cows. J Dairy Sci 68: $2817-2826$

Yusuf M, Nakao T, Ranasinghe RBK, Gautam G, Long ST, Yoshida C, Koike K, Hayashi A 2010: Reproductive performance of repeat breeders in dairy herds. Theriogenology 73: 1220-1229

Yusuf M, Rahim L, Asja MA, Wahyudi A 2012: The incidence of repeat breeding in dairy cows under tropical condition. Media Peternakan 35: 28-31 